\title{
Keanekaragaman Jenis Tumbuhan Paku (Pteridophyta) Berdasarkan Topografi di Kawasan Hutan Suaka Margasatwa Lambusango Kabupaten Buton
}

\author{
Arwan bin Laeto ${ }^{1}$, Fahmil lkhsan Taharu ${ }^{2^{*}}$ \\ ${ }^{1}$ Fakultas Kedokteran, Universitas Sriwijaya, Indonesia \\ 2 Fakultas Keguruan dan IImu Pendidikan, Universitas Muhammadiyah Buton, Indonesia \\ *Korespondensi: $\underline{\text { fahmilikhsanbiologik3@gmail.com }}$
}

\begin{tabular}{|c|c|}
\hline & \multirow{6}{*}{ 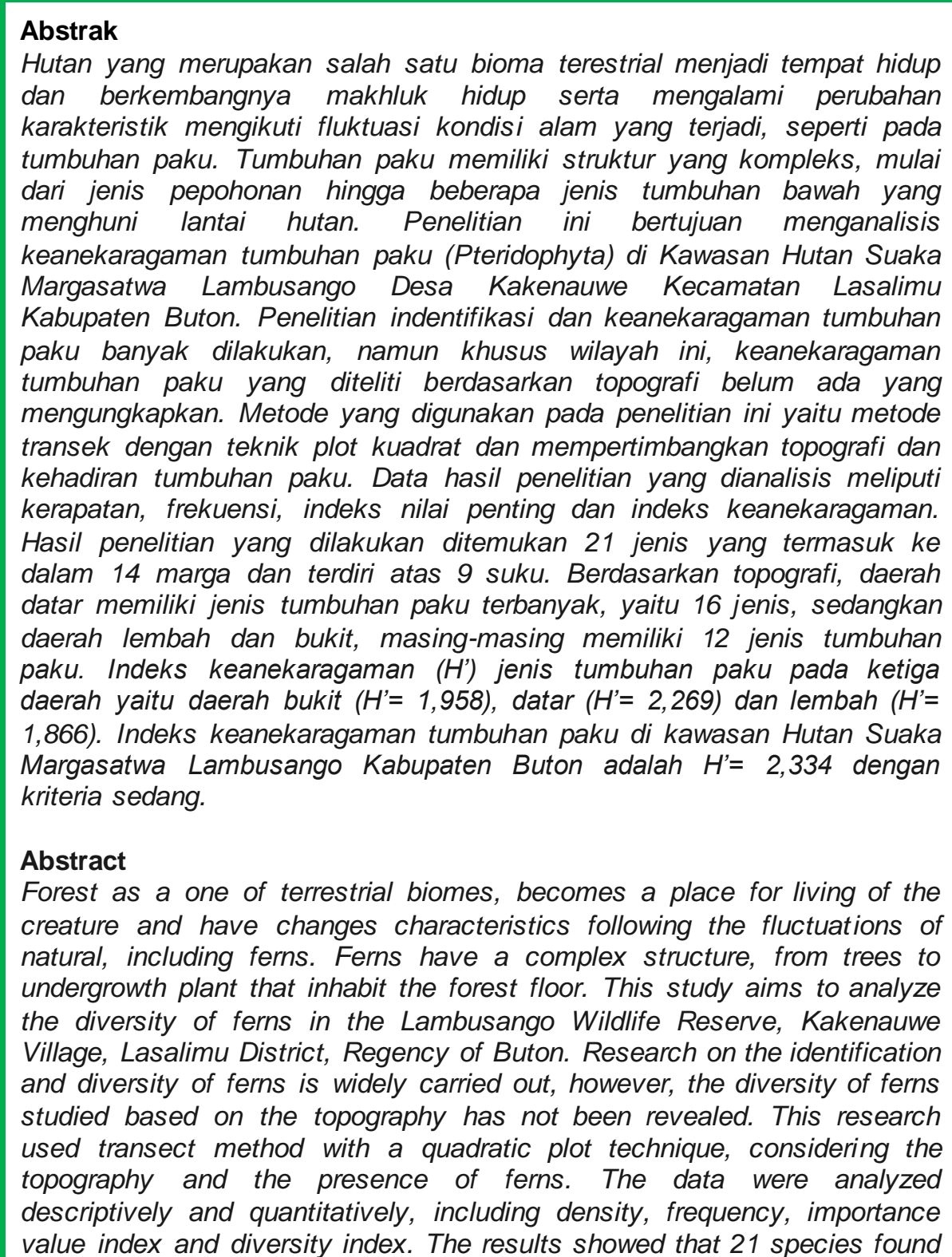 } \\
\hline Diterim & \\
\hline & \\
\hline , & \\
\hline & \\
\hline & \\
\hline
\end{tabular}


including 14 genera and 9 orders. Based on the topography, the flat area has the most types of ferns, namely 16 species, while the valley and hill areas have 12 types respectively. Diversity index $\left(H^{\prime}\right)$ of ferns in the three regions, namely the hill area $\left(H^{\prime}=1.958\right)$, flat $\left(H^{\prime}=2.269\right)$ and valleys $\left(H^{\prime}=\right.$ 1.866). The index of fern diversity in the Lambusango Wildlife Reserve, Buton Regency is $H^{\prime}=2,334$ with moderate criteria. .

\section{Pendahuluan}

Indonesia merupakan negara yang memiliki banyak kawasan hutan, baik yang dilindungi maupun yang tidak dilindungi (Indriyanto, 2010). Kawasan hutan ini menjadikan Indonesia sebagai salah satu negara tropis yang memiliki keanekaragaman fauna yang tinggi (Surfiana et al., 2018). Berdasarkan Surat Keputusan Menteri Pertanian Nomor: 639/Kpts/9/Um/1982 Tanggal 1 Sepetember 1982, salah satu hutan yang dilindungi di daerah Sulawesi Tenggara adalah Kawasan Hutan Suaka Margasatwa Lambusango dengan luas kurang lebih 27.700 ha, yang secara geografis terletak antara $05^{\circ} 12^{\prime}-05^{\circ} 24^{\prime}$ lintang selatan

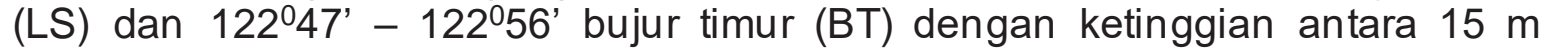
sampai $780 \mathrm{~m}$ di atas permukaan laut (dpl) (Purwanto, 2007). Hutan ini memiliki topografi alam datar, lembah dan berbukit dengan curah hujan berkisar 1.980 $\mathrm{mm} / \mathrm{tahun}$, suhu udara berkisar antara $20-34^{\circ} \mathrm{C}$ dan kelembaban berkisar $80 \%$ (BKSDA, 2018).

Keanekaragaman jenis tumbuhan yang terdapat di Kawasan Hutan Suaka Margasatwa Lambusango memiliki struktur yang kompleks, mulai dari jenis pepohonan yang mendominasi kawasan hutan sampai dengan beberapa jenis tumbuhan bawah yang menghuni lantai hutan (Uji \& Windadri, 2007). Berbagai jenis tumbuhan ini hidup bersaing secara alami untuk mendapatkan cahaya, ruang tumbuh, hara mineral dan air diantaranya adalah jenis tumbuhan paku (Pteridophyta). Tumbuhan ini memegang peranan penting dalam menyediakan kandungan bahan organik yang bervariasi pada lantai hutan sehingga meningkatkan kapasitas peresapan air yang lebih tinggi (Loveless, 1989). Tingginya variasi kandungan bahan organik yang berasal dari jumlah serasah yang dihasilkan memberikan penutupan lahan, sehingga berfungsi efektif untuk mengendalikan erosi (Kinho, 2011). Selain itu, secara akademik, keanekaragaman jenis tumbuhan dapat memberikan gambaran tentang jumlah populasi dalam suatu komunitas dan usia komunitas tersebut karena keanekaragaman cenderung menjadi tinggi di dalam komunitas yang lebih tua, dan rendah dalam komunitas yang baru terbentuk (Indriyanto, 2006).

Tumbuhan paku dapat tumbuh tersebar di dalam kawasan hutan. Hal ini disebabkan kemampuan adaptasi yang tinggi terhadap kondisi lingkungan hutan, sehingga dapat dijumpai baik pada tanah (paku terestrial) maupun pada pepohonan yang hidup menempel (paku epifit). Paku yang termasuk jenis terestrial menyukai kondisi lingkungan yang lembab dan ternaung, di sekitar daerah aliran sungai dan di daerah pegunungan yang memiliki kelembaban tinggi (Sari \& Bayu, 2019). Namun, ada pula yang tumbuh pada tempat yang cukup cerah dan kering, di sepanjang pinggir jalan. Hal ini menunjukkan bahwa kondisi lingkungan ikut menentukan karakteristik, pola penyebaran dan keanekaragaman tumbuhan paku tersebut (Steenis, 2008). Penelitian keanekaragaman tumbuhan paku berdasarkan 
topografi hutan di Indonesia masih sangat minim dilaporkan. Berdasarkan uraian tersebut maka peneliti menganggap penting untuk dilakukan penelitian yang bertujuan untuk mengetahui keanekaragaman jenis tumbuhan paku berdasarkan topografi di kawasan hutan Suaka Margasatwa Lambusango Kabupaten Buton.

\section{Metode Penelitian}

Penelitian menggunakan metode transek dengan teknik plot kuadrat yang diletakkan secara berselang-seling sepanjang garis transek. Teknik ini dipilih berdasarkan keadaan topografi lokasi dan keberadaan tumbuhan paku. Setiap sampel tumbuhan paku yang telah diperoleh didokumentasi, lalu satu sampel diambil dan dicatat ke dalam buku kolektor terkait lokasi, tanggal, nama daerah dan habitat tempat tumbuh. Setiap jenis paku dihitung jumlah individu yang terdapat di dalam plot pengamatan pada masing-masing area topografi yang berbeda (datar, lembah dan bukit). Tumbuhan yang telah diperoleh di lokasi penelitian yang sudah diketahui baik nama lokal, Indonesia maupun nama latinnya langsung diidentifikasi di lapangan menggunakan buku kunci identifikasi seperti buku Sastrapradja (1980), Steenis (2008) dan Tjitrosoepomo (2010).

Pengukuran factor lingkungan meliputi suhu udara, kelembaban udara, $\mathrm{pH}$ tanah, intensitas cahaya dan ketinggian area dari permukaan laut. Teknik analisis data yang digunakan dalam penelitian ini adalah analisis deskriptif kualitatif yang mengacu pada buku-buku identifikasi dan analisis kuantitatif yang men gacu pada buku-buku ekologi. Data yang dianalisis berupa identitas tumbuhan (nama lokal, Indonesia dan Latin), deskripsi ciri-ciri morfologi, kerapatan spesies, frekuensi, indek nilai penting dan indeks keanekaragaman (Indriyanto, 2006).

\section{Hasil dan Pembahasan}

Kawasan Hutan Suaka Margasatwa Lambusango merupakan salah satu tipe kawasan hutan konservasi dengan ciri khas tertentu yang mempunyai fungsi pokok pengawetan keanekargaman tumbuhan dan satwa serta ekosistem. Suaka margasatwa ialah kawasan suaka alam yang mempunyai ciri khas berupa keanekaragaman dan keunikan jenis tumbuhan dan satwa (Indriyanto, 2006). Hutan ini terletak di Desa Kakenauwe Kecamatan Lasalimu Kabupaten Buton dengan luas sekitar 27.700 ha. Hutan ini secara geografis terletak antara 4035'4057' LS dan $122^{\circ} 45^{\prime}-122^{\circ} 55^{\prime}$ BT. Selain itu, hutan ini harus tetap dipertahankan sebagai hutan dengan penutupan vegetasi secara tetap sebagai sistem penyangga kehidupan untuk mengatur tata air, mencegah banjir, mengendalikan erosi dan memelihara kesuburan tanah. Kawasan ini digunakan sebagai tempat penelitian karena memiliki keanekaragaman tumbuhan, baik tumbuhan tingkat tinggi maupun tumbuhan tingkat rendah yang harus tetap dipertahankan keberadaan dan kelestariannya.

Kondisi suhu udara pada lokasi penelitian secara umum berkisar antara 26 $28{ }^{\circ} \mathrm{C}$, tertinggi pada daerah lembah titik I karena sedikitnya kanopi tumbuhan tegakan, dan terendah pada 4 titik, yaitu titik II dan III pada daerah datar, titik I pada daerah bukit dan titik II pada daerah lembah yang disebabkan luasnya penutupan kanopi tumbuhan tegakan serta banyaknya tumbuhan liana yang merambat antar pohon. Kelembaban udara berkisar antara $82-70 \%$, tertinggi pada titik III di daerah datar dan lembah akibat tutupan vegetasi yang padat, sedangkan terendah pada titik I di daerah bukit karena jarak antar pohon relatif jauh antara satu dengan lainnya. Suhu tanah berkisar antara $24-26^{\circ} \mathrm{C}$ dan $\mathrm{pH}$ 
tanah berkisar antara 6,5 - 6,8. Intensitas cahaya berkisar antara $2420-10200$ Lux dan ketinggian tempat berkisar antara $210-260 \mathrm{~m}$ dpl. Kawasan hutan ini dihuni oleh beranekaragam jenis tumbuhan baik tumbuhan tinggi maupun komunitas tumbuhan bawah yang menghuni lantai hutan diantaranya adalah jen is tumbuhan paku.

\subsection{Hasil}

\subsubsection{Komposisi Tumbuhan Paku}

Komposisi tumbuhan paku merupakan jumlah spesies ataupun banyaknya individu dari suatu jenis tumbuhan paku. Hasil penelitian menunjukkan bahwa terdapat 21 jenis tumbuhan paku yang ditemukan di lokasi penelitian dengan jumlah individu sebanyak 4.138 yang termasuk kedalam 14 marga dan terdiri atas 9 suku. Jenis-jenis tumbuhan paku tersebut dapat dilihat pada Tabel 1.

Tabel 1. Jenis Tumbuhan Paku (Pteridophyta) Terestrial yang Terdapat di lokasi penelitian.

\begin{tabular}{lll}
\hline No & Jenis & Marga \\
\hline 1 & Adiantum cuneatum Langsd \& Fisch & Adiantum \\
\hline 2 & Angiopteris avecta Hoofm. & Angiopteris \\
\hline 3 & Tectaria angulata Willd. Copel. & Tectaria \\
\cline { 2 - 3 } 4 & Tectaria sp. & Tectaria \\
\hline 5 & Davallia denticulata (Burm) Mett. & Davallia \\
\hline 6 & Lindsaea ensifolia Sw. & Lindsaea \\
\hline 7 & Selaginella willdenowii Backer. & Selaginella \\
\cline { 2 - 3 } 8 & Selaginella plana Hieron. & Selaginella \\
\hline 9 & Antrophyum semicostatum Desv. & Antrophyum \\
\hline 10 & Asplenium polyodon G. Forster. & Asplenium \\
\hline 11 & Microsorium pteropus (Bl.) Ching & Microsorium \\
\cline { 2 - 3 } 12 & Microsorium sp. & Microsorium \\
\hline 13 & Nephrolepis hirsutula (Forst.) Pr. & Nephrolepis \\
\hline 14 & Pteris ensiformis Burm. & Pteris \\
\hline 15 & Lygodium circinatum Sw. & Lygodium \\
\hline 16 & Christella dentata Forst. & Christella \\
\cline { 2 - 3 } 17 & Christella parasitica (L.) H. Lev. & Christella \\
\hline 18 & Coryphopteris tahanensis Holtt. & Coryphopteris \\
\cline { 2 - 3 } 19 & Coryphopteris sp. & Coryphopteris \\
\hline 20 & Pyrrosia numularifolia & Pyrrosia \\
\hline 21 & Stenochlaena palustris & Stenochlaena \\
\hline
\end{tabular}

Sumber: Diolah dari hasil penelitian

\subsubsection{Kerapatan Jenis Tumbuhan Paku}

Kerapatan jenis tumbuhan paku terestrial di lokasi penelitian diketahui bah wa jenis tumbuhan paku terestrial yang memiliki kerapatan tertinggi pada daerah lembah adalah jenis Selaginella wildenowii (Desv.) Backer. yakni 8,5 ind $/ \mathrm{m}^{2}$ dengan kerapatan relatif yakni 59,079 \%, sedangkan kerapatan terendah terdapat pada jenis Asplenium polyodon G. Forster. dengan kerapatan yaitu 0,025 ind $/ \mathrm{m}^{2}$ dan kerapatan relatifnya sebesar $0,173 \%$. Selanjutnya pada daerah bukit, kerapatan tertinggi adalah jenis Selaginella willdenowii (Desv.) Backer. yaitu $11,162 \mathrm{ind} / \mathrm{m}^{2}$ dengan kerapatan relatif yakni $60,914 \%$, sedangkan kerapatan terendah yaitu pada jenis Tectaria angulata Willd. Copel. dengan kerapatan 0,012 ind $/ \mathrm{m}^{2}$ dan kerapatan relatifnya yakni $0,068 \%$. Jenis tumbuhan paku pada daerah 
datar yang memiliki kerapatan tertinggi adalah Selaginella willdenowii (Desv.) Backer. yaitu $5,275 \mathrm{ind} / \mathrm{m}^{2}$ dengan kerapatan relatif yakni $27,744 \%$, sedangkan kerapatan terendah terdapat pada jenis Antrophyum semicostatum Desv. dengan kerapatan yakni $0,025 \mathrm{ind} / \mathrm{m}^{2}$ dan kerapatan relatifnya sebesar $0,131 \%$. Perbedaan kerapatan jenis tumbuhan paku dapat disebabkan oleh faktor penyebaran spora matang dari tumbuhan paku yang terjadi secara alami oleh tiupan angin maupun melalui perantaraan hewan yang melintasi daerah tumbuhan paku tersebut (Piggott, 1988)

\subsubsection{Frekuensi Jenis Tumbuhan Paku}

Frekuensi jenis tumbuhan paku terestrial di lokasi penelitian diketahui bahwa jenis tumbuhan paku terestrial yang memiliki frekuensi tertinggi pada daerah lembah adalah jenis Lygodium circinatum Sw. yakni 0,9 dengan frekuensi relatif yakni 20,224 \%, sedangkan frekuensi terendah terdapat pada jenis Asplenium polyodon G. Forster. dengan frekuensi yakni 0,05 dan frekuensi relatifnya sebesar $1,123 \%$. Selanjutnya pada daerah bukit, frekuensi tertinggi adalah jenis Selaginella willdenowii (Desv.) Backer. yaitu 1,0 dengan frekuensi relatif sebesar 23,529 \%, sedangkan frekuensi terendah yaitu pada jenis Adiantum cuneatum Langsd. \& Fisch. dan Tectaria angulata Willd. Copel., dengan frekuensi 0,05 dan frekuensi relatifnya yakni $1,176 \%$. Jenis tumbuhan paku pada daerah datar yang memiliki frekuensi tertinggi adalah Selaginella willdenowii (Desv.) Backer. yaitu 0,85 dengan frekuensi relatif yakni 18,888 \%, sedangkan frekuensi terendah terdapat pada jenis Microsorium sp. dan Antrophyum semicostatum Desv. dengan frekuensi yakni 0,05 dan frekuensi relatifnya sebesar $1,111 \%$. Faktor variasinya kemampuan adaptasi menyebabkan adanya perbedaan frekuensi jenis tu mbu han paku yang tumbuh pada daerah tertentu dengan beragam kondisi lingkungan abiotiknya (Syafei, 1994).

\subsubsection{Indeks Nilai Penting Tumbuhan Paku}

Indeks nilai penting jenis tumbuhan paku terestrial di lokasi penelitian diketahui bahwa jenis tumbuhan paku terestrial yang memiliki indeks nilai penting tertinggi pada daerah lembah adalah jenis Selaginella wilidenowii (Desv.) Backer. yakni $73,685 \%$, sedangkan indeks nilai penting terendah terdapat pada jenis Asplenium polyodon G. Forster. dengan indeks nilai penting adalah 1,297 \%. Selanjutnya pada daerah bukit, indeks nilai penting tertinggi adalah jenis Selaginella willdenowii (Desv.) Backer. yaitu 84,443\%, sedangkan indeks nilai penting terendah yaitu pada jenis Tectaria angulata Willd. Copel. dengan indeks nilai penting $1,244 \%$. Jenis tumbuhan paku pada daerah datar yang memiliki indeks nilai penting tertinggi adalah Selaginella willdenowii (Desv.) Backer. yaitu 46,633\%, sedangkan indeks nilai penting terendah terdapat pada jenis Antrophyum semicostatum Desv. dengan indeks nilai penting yakni 1,242\%. Perbedaan ini disebabkan faktor rentang toleransi pada jenis tumbuhan paku tertentu yang berbeda satu dengan yang lain terhadap lingkungan (Odum, 1996).

\subsubsection{Indeks Keanekaragaman Tumbuhan Paku}

Nilai Indeks Keanekaragaman ( $\left.\mathrm{H}^{\prime}\right)$, berdasarkan hasil analisis yang dapat dilihat pada Tabel 2, 3, dan 4, menunjukkan bahwa pada daerah lembah, bukit, dan datar memiliki indeks keanekaragaman $\left(\mathrm{H}^{\prime}\right)$ masing-masing sebesar 1,958, 1,866 dan 2,269. 
Tabel 2. Indeks Keanekaragaman Jenis Tuambuhan Paku Pada Daerah Lembah

\begin{tabular}{clc}
\hline No. & Nama Jenis & $\mathrm{Pi.LnPi}$ \\
\hline 1. & Adiantum cuneatum & 0,072 \\
\hline 2. & Asplenium polyodon & 0,032 \\
\hline 3. & Christella dentata & 0,213 \\
\hline 4. & Christella parasitica & 0,056 \\
\hline 5. & Coryphopteris tahanensis & 0,134 \\
\hline 6. & Pyrrosia numularifolia & 0,129 \\
\hline 7. & Stenochlaena palustris & 0,25 \\
\hline 8. & Lygodium circinnatum & 0,297 \\
\hline 9. & Microsorum sp. & 0,056 \\
\hline 10. & Nephrolepis hirsutula & 0,143 \\
\hline 11. & Pteris ensiformis Burm. & 0,204 \\
\hline 12. & Selaginella willdenowii & 0,367 \\
\hline & Jumlah & 1,958 \\
\hline
\end{tabular}

Sumber: Data diolah dari hasil penelitian

Tabel 3. Indeks Keanekaragaman Jenis Tuambuhan Paku Pada Daerah Bukit

\begin{tabular}{clc}
\hline No. & Nama Jenis & $\mathrm{Pi.LnPi}$ \\
\hline 1. & Adiantum cuneatum & 0,034 \\
\hline 2. & Christella dentata & 0,145 \\
\hline 3. & Christella parasitica & 0,188 \\
\hline 4. & Coryphopteris tahanensis & 0,147 \\
\hline 5. & Pyrrosia numularifolia & 0,062 \\
\hline 6. & Lygodium circinnatum & 0,249 \\
\hline 7. & Microsorium pteropus & 0,069 \\
\hline 8. & Microsorum sp. & 0,08 \\
\hline 9. & Selaginella plana & 0,265 \\
\hline 10. & Selaginella willdenowii & 0,364 \\
\hline 11. & Tectaria angulata & 0,031 \\
\hline 12. & Tectaria sp. $\quad$ Jumlah & 0,228 \\
\hline & & 1,866
\end{tabular}

Sumber: Data diolah dari hasil penelitian

Tabel 4. Indeks Keanekaragaman Jenis Tuambuhan Paku Pada Daerah Datar

\begin{tabular}{clc}
\hline No. & Nama Jenis & $\mathrm{Pi.LnPi}$ \\
\hline 1. & Angiopteris avecta & 0,057 \\
\hline 2. & Antrophyum semicostatum & 0,031 \\
\hline 3. & Asplenium polyodon & 0,263 \\
\hline 4. & Christella dentata & 0,08 \\
\hline 5. & Christella parasitica & 0,146 \\
\hline 6. & Coryphopteris tahanensis & 0,18 \\
\hline 7. & Coryphopteris sp. & 0,098 \\
\hline 8. & Davallia denticulata & 0,065 \\
\hline 9. & Pyrrosia numularifolia & 0,056 \\
\hline 10. & Lindsaea ensifolia & 0,09 \\
\hline 11. & Lygodium circinnatum & 0,14 \\
\hline 12. & Microsorium pteropus & 0,094 \\
\hline 13. & Microsorum sp. & 0,035 \\
\hline 14. & Selaginella plana & 0,304 \\
\hline 15. & Selaginella willdenowii & 0,339
\end{tabular}




\begin{tabular}{lll} 
16. Tectaria sp. & & 0,283 \\
\hline & Jumlah & 2,269 \\
\hline
\end{tabular}

Sumber: Data diolah dari hasil penelitian

Berdasarkan analisis nilai kerapatan, kerapatan relatif, frekuensi, frekuensi relatif, dan indeks nilai penting, maka diperoleh indeks keanekaragaman $\left(\mathrm{H}^{\prime}\right)$ secara keseluruhan pada Kawasan Hutan Suaka Margasatwa Lambusango Desa Kakenauwe Kecamatan Lasalimu Kabupaten Buton dapat dilihat pada Tabel 5.

Tabel 5. Indeks Keanekaragaman Keseluruhan Jenis Tumbuhan Paku

\begin{tabular}{clc}
\hline No. Nama Jenis & Pi. LnPi \\
\hline 1. & Adiantum cuneatum & 0,039 \\
\hline 2. & Angiopteris avecta & 0,024 \\
\hline 3. & Antrophyum semicostatum & 0,013 \\
\hline 4. & Asplenium polyodon & 0,147 \\
\hline 5. & Christella dentata & 0,152 \\
\hline 6. & Christella parasitica & 0,139 \\
\hline 7. & Coryphopteris sp. & 0,044 \\
\hline 8. & Coryphopteris tahanensis & 0,155 \\
\hline 9. & Davallia denticulata & 0,028 \\
\hline 10. & Pyrrosia numularifolia & 0,085 \\
\hline 11. & Stenochlaena palustris & 0,118 \\
\hline 12. & Lindsaea ensifolia & 0,039 \\
\hline 13. & Lygodium circinnatum & 0,237 \\
\hline 14. & Microsorum pteropus & 0,062 \\
\hline 15. & Microsorum sp. & 0,058 \\
\hline 16. & Nephrolepis hirsutula & 0,061 \\
\hline 17. & Pteris ensiformis & 0,095 \\
\hline 18. & Selaginella plana & 0,239 \\
\hline 19. & Selaginella willdenowii & 0,366 \\
\hline 20. & Tectaria angulata & 0,012 \\
\hline 21. & Tectaria sp. & 0,21 \\
\hline & & 2,334 \\
\hline
\end{tabular}

Sumber: Data diolah dari hasil penelitian

\subsection{Pembahasan}

Berdasarkan hasil penelitian, jenis tumbuhan paku yang ditemukan di setiap daerah memiliki perbedaan komposisi yang signifikan. Hal ini disebabkan karena setiap jenis tumbuhan paku memiliki batas toleransi terhadap kondisi lingkungan yang bervariasi untuk dapat tu mbuh, bertahan hidup dan berkembang (Surfiana et al., 2018). Hal ini sesuai dengan hukum toleransi dalam suatu laporan penelitian yang menyatakan bahwa untuk setiap faktor lingkungan suatu jenis mempunyai kondisi minimum dan maksimum yang dapat dipikulnya, diantara kedua nilai ekstrim ini merupakan kisaran toleransi dan termasuk suatu kondisi optimum (Muswita et al., 2013).

Berdasarkan hasil penelitian, pada daerah lembah tumbuhan paku yang memiliki kerapatan tertinggi adalah jenis Selaginella willdenowii (Desv.) Backer., sedangkan terendah terdapat pada jenis Asplenium polyodon G. Forster. Kelembaban udara pada daerah ini adalah berkisar antara 80-82 \% dengan intensitas cahaya berkisar antara 2420-7900 Lux. Jenis Selaginella willdenowii (Desv.) Backer., dan seringkali membentuk belukar yang cukup lebat. 
Pertumbuhannya yang cukup subur disebabkan oleh tingginya tingkat toleransi jenis ini terhadap kondisi lingkungan hutan yang lembab, sehingga mempunyai kemampuan menguasai suatu kawasan. Jenis ini hidup di tanah terutama di tempat yang basah dan lembab pada dataran rendah. Sedangkan jenis dari marga Asplenium umumnya tu mbuh secara epifit dan banyak ditemukan di daerah hutan pegunungan (Imaniar \& Murdiyah, 2017). Hal ini sejalan dengan penelitian yang dilaporkan bahwa tumbuhan ini biasanya banyak ditemui di daerah -daerah hutan pegunungan yang ketinggiannya mencapai $1500 \mathrm{~m}$ lebih di atas permukaan laut dan kebanyakan tumbuhnya epifit, terutama pada sela-sela pohon yang berlumut (Salamah et al., 2020).

Kerapatan tertinggi pada daerah bukit terdapat pada jenis Selaginella willdenowii (Desv.) Backer. dan terendah terdapat pada jenis Tectaria angulata Willd. Copel. Faktor lingkungan pada daerah ini berdasarkan hasil pengukuran yakni kelembaban udara berkisar antara $70-76 \%$ dan intensitas cahaya berkisar antara 2900 - 10200 Lux serta berada pada ketinggian tempat yang berkisar antara 250 - $260 \mathrm{~m}$ dpl. Hal ini karena selain menyukai tempat yang lembab, jenis dari marga Selaginella ini juga umumnya tumbuh dengan baik pada kondisi lingkungan yang terdedah dengan luas penutupan tajuk pohon yang tidak rapat. Jenis ini hidup di tanah pada tempat cerah sinar matahari dan agak keteduhan. Keberadaan jenis ini berfungsi untuk mencegah erosi. Sedangkan jenis Tectaria angulata Willd. Copel. tidak toleran terhadap cerah sinar matahari dan tumbuhnya lebih lambat (Steenis, 2008). Tumbuhan paku yang menyukai tempat yang teduh biasanya tumbuh lebih lambat dibandingkan dengan tumbuhan yang menyukai sinar matahari (Ayatusa'adah \& Nor, 2017).

Pada daerah datar (220-230 m dpl), kerapatan tertinggi terdapat pada jenis Selaginella willdenowii (Desv.) Backer. sedangkan terendah terdapat pada jenis Antrophyum semicostatum Desv. Jenis dari marga Selaginella tumbuh baik di daerah ini karena memiliki tingkat asosiasi yang tinggi terhadap tumbuhan lain. Hal ini sejalan dengan sebuah penelitian yang dilaporkan bahwa tumbuhan ini terdapat di lereng-lereng bukit dan tumbuhnya seringkali bercampur dengan jenis dari marga Lygodium, Gleichenia dan Selaginella lainnya (Sari \& Bayu, 2019). Kon disi lingkungan pada daerah ini agak lembab (75-82 \%) dan ternaung yang ditandai dengan intensitas cahaya yang rendah (2880 - 6900 lux), sehingga jenis Antrophyum semicostatum Desv. jumlahnya relatif sedikit jika dibandingkan dengan jenis Selaginella willdenowii (Desv.) Backer. Jenis Antrophyum semicostatum Desv. umumnya tumbuh dengan baik secara epitif (Salamah et al., 2020).

Jika dilihat dari nilai kerapatan seluruh jenis tumbuhan paku yang berada pada luas area $240 \mathrm{~m}^{2}$, menunjukkan bahwa kerapatan tertinggi terdapat pada jenis Selaginella willdenowii (Desv.) Backer. sedangkan kerapatan terendah terdapat pada jenis Tectaria angulata Willd. Copel. Jenis Selaginella willdenowii (Desv.) Backer. memiliki kerapatan tertinggi secara keseluruhan disebabkan oleh kondisi faktor lingkungan yang mendukung pertumbuhannya. Berdasarkan hasil penelitian bahwa jenis paku ini tumbuh dengan baik pada 3 daerah tempat pengambilan sampel yakni pada daerah lembah, bukit dan datar. Jenis ini hidup di tanah terutama di tempat yang basah baik di dataran rendah maupun di dataran tinggi hingga ketinggian $1200 \mathrm{~m} \mathrm{dpl} \mathrm{(Fitriasih} \mathrm{et} \mathrm{al.,} \mathrm{2019).} \mathrm{Faktor} \mathrm{abiotik} \mathrm{seperti}$ kelembaban udara yang berkisar antara 74-82 \%, ketinggian tempat antara 220- 
$260 \mathrm{~m}$ dpl dengan suhu tanah dan $\mathrm{pH}$ tanah yang masing-masing berkisar antara 24-26 ${ }^{\circ} \mathrm{C}$ dan 6,5-6,8 menjadi penentu tingginya kerapatan jenis tumbuhan paku tersebut. Hal ini menjelaskan bahwa jenis Selaginella willdenowii (Desv.) Backer memiliki kemampuan adaptasi terhadap kondisi lingkungan yang demikian sehingga pada lokasi penelitian jenis ini jumlahnya lebih mendominasi dibandingkan jenis tumbuhan paku lainnya (Astuti et al., 2017).

Kerapatan terendah secara keseluruhan terdapat pada jenis Tectaria angulata Willd. Copel. yang ditemukan hanya di daerah bukit. Hal ini disebabkan oleh rendahnya tingkat penguasaan terhadap kondisi lingkungan dalam memperebutkan unsur hara dan ruang tumbuh bagi kehidupan jenis paku tersebut. Jenis paku dari marga Tectaria ini merupakan salah satu paku-pakuan yang tumbuh di dataran tinggi dan melaporkan bahwa semakin tinggi area tersebut dari pemukaan laut, maka semakin sedikit jumlah individu paku-pakuan yang ditemukan. Biasanya dapat tumbuh hingga ketinggian $1500 \mathrm{~m}$ dpl dan sampai saat ini belum ada yang melaporkan jenis ini terdapat di dataran rendah (Imaniar \& Murdiyah, 2017).

Frekuensi spesies tumbuhan paku adalah jumlah petak contoh tempat ditemukannya suatu spesies dari sejumlah petak contoh yang dibuat (Putrawan, 2014). Berdasarkan hasil penelitian, pada daerah lembah tumbuhan paku yang memiliki frekuensi tertinggi adalah jenis Lygodium circinatum Sw., sedangkan terendah terdapat pada jenis Asplenium polyodon G. Forster. Jenis Lygodium circinatum Sw. tumbuh dan berkembang dengan baik di daerah ini karena kemampaun mendapatkan sinar matahari walaupun berada dalam daerah den gan penutupan kanopi yang tinggi. Selain itu, jenis dari marga ini merupakan jenis paku yang menjalar dan selalu merambat pada tumbuhan lain melalui daunnya yang melilit tumbuhan lain yang ada didekatnya sehingga dapat tersebar secara merata di daerah tersebut (Syafrudin et al., 2016). Sedangkan jenis Asplenium polyodon G. Forster. sangat menyukai daerah tepi aliran sungai. Jenis dari maraga Asplenium mudah dijumpai di daerah-daerah dataran tinggi, pada tebing-tebing dan tepi aliran sungai (Apriyanti \& Santri, 2017).

Frekuensi tertinggi pada daerah bukit terdapat pada jenis Selaginella willdenowii (Desv.) Backer. dan terendah terdapat pada 2 jenis tumbuhan paku, yaitu Adiantum cuneatum Langsd. \& Fisch. Dan Tectaria angulata Willd. Copel. Hal ini karena jenis Selaginella willdenowii (Desv.) Backer. memiliki kisaran toleransi terhadap faktor lingkungan yang luas, yakni mampu hidup di tempat yang lembab dan pada kondisi lingkungan yang terdedah dengan luas penutupan tajuk pohon yang tidak rapat sehingga ditemukan dalam semua plot yang dibuat di daerah tersebut. Jenis ini hidup di tanah pada tempat cerah sinar matahari dan agak keteduhan. Selain berfungsi untuk mencegah erosi, tumbuhan ini juga banyak ditemukan hidup di dataran rendah maupun di dataran tinggi (Syafrudin et al., 2016). Sedangkan jenis Adiantum cuneatum Langsd. \& Fisch. Jarang ditemukan di daerah dataran tinggi. Tumbuhan ini sering ditemukan tumbuh di tepi sungai dan di tebing-tebing pada tempat yang agak terbuka (Sari \& Bayu, 2019).

Pada daerah datar, frekuensi tertinggi tumbuhan paku terdapat pada jenis Selaginella willdenowii (Desv.) Backer. sedangkan terendah terdapat pada jenis Microsorium sp. dan Antrophyum semicostatum Desv. Kondisi lingkungan pada daerah ini lembab (kelembaban udara 80-82\%) dan ternaung yang ditandai dengan intensitas cahaya yang rendah (2880 - 3220 lux), sehingga jenis 
Selaginella willdenowii (Desv.) Backer. jumlahnya relatif banyak jika dibandingkan dengan jenis Microsorium sp. dan Antrophyum semicostatum Desv. Hal ini disebabkan jenis Selaginella willdenowii (Desv.) Backer. memiliki daya penyebaran spora tinggi, daya tumbuh spora yang tinggi dan kisaran toleransi lingkungan yang luas. Dispersi bakal kehidupan (spora) individu anggota populasi berpengaruh terhadap perluasan daerah teritori populasi tersebut (Indriyanto, 2006).

Jika dilihat dari frekuensi seluruh jenis tumbuhan paku yang berada pada 60 plot pengamatan, menunjukkan bahwa frekuensi tertinggi terdapat pada jenis Selaginella willdenowii (Desv.) Backer. sedangkan frekuensi terendah terdapat pada jenis Tectaria angulata Willd. Copel. Dan Antrophyum semicostatum Desv. Jenis Selaginella willdenowii (Desv.) Backer. memiliki frekuensi tertinggi secara keseluruhan disebabkan oleh tingginya kemampuan jenis tersebut dalam menyesuaikan diri dengan lingkungan yang ada dan dapat bersaing terhadap jen is lain (Astuti et al., 2017). Hal ini dapat dilihat dari jumlah plot dimana diketemukannya jenis ini, yaitu 50 plot dari 60 plot secara keseluruhan. Makin banyak petak contoh (plot) yang di dalamnya ditemukan suatu spesies, berarti makin besar frekuensi spesies tersebut (Putrawan, 2014). Berdasarkan hasil penelitian bahwa jenis paku ini tumbuh dengan baik pada 3 daerah tempat pengambilan sampel yakni pada daerah lembah, bukit dan datar. Kelembaban udara pada wilayah ini berkisar antara 74-82 \% yang berada pada ketinggian antara 220-260 $\mathrm{m}$ dpl dengan suhu tanah dan $\mathrm{pH}$ tanah yang masing-masing berkisar antara $24-26{ }^{\circ} \mathrm{C}$ dan 6,5-6,8 serta intensitas cahaya berkisar antara 2420 - 10200 Lux.

Frekuensi terendah terdapat pada jenis Tectaria angulata Willd. Copel. dan Antrophyum semicostatum Desv. yang tidak ditemukan di daerah lembah. Hal ini disebabkan oleh rendahnya daya kompetisi tumbuhan ini terhadap tu mbu h an Iain baik dalam memperebutkan unsur hara dan ruang tumbuh bagi kehidupan kedua jenis paku tersebut. Jenis paku dari marga Tectaria ini merupakan salah satu paku-pakuan yang tumbuh di dataran tinggi. Biasanya dapat tumbuh hingga ketinggian $1500 \mathrm{~m}$ dpl (Sastrapradja, 1980). Sedangkan Antrophyum semicostatum Desv. umumnya tumbuh secara epifit pada tumbuhan kayu yang ada di sekitarnya, sehingga jarang ditemukan tumbuh di atas permukaan tanah. Selain itu, keberadaan paku jenis epifit bergantung pada pohon yang menjadi inangnya dan tumbuh pada lingkungan serta topografi tertentu (Musriadi et al., 2017).

Indeks nilai penting (INP) spesies tumbuhan paku merupakan jumlah dari persentase kerapatan dan persentase frekuensi. Indeks nilai penting (INP) menyatakan kepentingan suatu jenis tu mbu han serta memperlihatkan peranan nya dalam komunitas, di mana nilai penting itu diperoleh dari hasil penjumlahan kerapatan relatif $(K R)$ dan frekuensi relatif (FR) (Putrawan, 2014). Berdasarkan hasil penelitian, pada daerah lembah tumbuhan paku yang memiliki indeks nilai penting tertinggi adalah jenis Selaginella willdenowii (Desv.) Backer., sedangkan terendah terdapat pada jenis Asplenium polyodon G. Forster. Jenis Selaginella willdenowii (Desv.) Backer. tumbuh dan berkembang dengan baik di daerah ini karena memiliki daya mempertahankan diri dan efisiensi yang tinggi dalam memanfaatkan faktor lingkungan. Keberhasilan jenis-jen is tu mbuhan untuk tumbuh dan bertambah banyak tidak lepas dari daya mempertahankan diri pada kondisi lingkungan dan memiliki indeks nilai penting tertinggi (Wanira et al., 2018). 
Indeks nilai penting tertinggi pada daerah bukit terdapat pada jenis Selaginella willdenowii (Desv.) Backer. dan terendah terdapat pada Tectaria angulata Willd. Copel. Hal ini karena jenis Selaginella willdenowii (Desv.) Backer. memiliki kisaran toleransi terhadap faktor lingkungan yang luas, yakni mampu hidup di tempat yang lembab dan pada kondisi lingkungan yang terdedah dengan luas penutupan tajuk pohon yang tidak rapat. Tumbuhan yang mempunyai adaptasi tinggilah yang mampu hidup sukses di suatu daerah (Astuti et al., 2017).

Daerah datar indeks nilai penting tertinggi terdapat pada jenis Selaginella willdenowii (Desv.) Backer. sedangkan terendah terdapat pada jenis Antrophyum semicostatum Desv.. Kondisi lingkungan pada daerah ini lembab dan ternaung yang ditandai dengan intensitas cahaya yang rendah, mempengaruhi pertumbuhan dan penyebaran spora jenis ini, sehingga jenis Selaginella willdenowii (Desv.) Backer. memiliki kerapatan relatif dan frekuensi relatif yang lebih tinggi dibandingkan dengan jenis Antrophyum semicostatum Desv. Pertumbuhan suatu jenis tumbuhan selain dipengaruhi oleh faktor genetik juga dipengaruhi oleh interaksinya dengan lingkungan. Pengaruh lingkungan tersebut meliputi kelembaban udara, suhu udara, suhu tanah, $\mathrm{pH}$ tanah, ketinggian tempat dan intensitas cahaya (Wanira et al., 2018).

Indeks nilai penting seluruh jenis tumbuhan paku yang berada di lokasi penelitian menunjukkan bahwa indeks nilai penting tertinggi terdapat pada jenis Selaginella willdenowii (Desv.) Backer. sedangkan terendah terdapat pada jenis Tectaria angulata Willd. Copel. Jenis Selaginella willdenowii (Desv.) Backer. memiliki indeks nilai penting tertinggi secara keseluruhan karena jenis ini dapat menyesuaikan diri dengan kondisi lingkungan yang ada. Spesies-spesies yang dominan (yang berkuasa) dalam suatu komunitas tumbuhan akan memiliki in deks nilai penting yang tinggi. Meskipun frekuensi tertinggi tidak terdapat pada jenis ini (Indriyanto, 2006), namun jenis ini memiliki frekuensi relatif yang tinggi setelah jenis Lygodium circinatum Sw. Umumnya, jenis yang dominan adalah jenis-jenis di dalam suatu komunitas dengan produktivitas yang besar dan sebagian besar mengendalikan arus energi (Putrawan, 2014).

Indeks nilai penting terendah secara keseluruhan terdapat pada jenis Tectaria angulata Willd. Copel. kerena memiliki nilai kerapatan relatif dan frekuensi relatif yang sangat rendah. Hal ini mencerminkan rendahnya kemampuan jenis tersebut dalam menyesuaikan diri dengan lingkungan yang ada dan tidak dapat bersaing terhadap jenis lainnya. Spesies yang berhasil dalam bersaing bergantung kepada kisaran toleransi dan syarat-syarat ekologi yang dimiliki oleh suatu spesies tumbuhan (Kurniawati \& Rachmadiarti, 2010).

Keanekaragaman merupakan ukuran integrasi komunitas biologik dengan menghitung dan mempertimbangkan jumlah populasi yang membentuknya dengan kelimpahan relatifnya (Indriyanto, 2006). Berdasarkan hasil analisis, nilai indeks keanekaragaman $\left(H^{\prime}\right)$ tertinggi terdapat pada komunitas paku di daerah lembah datar, sedangkan terendah terdapat pada daerah bukit. Daerah datar memiliki nilai indeks keanekaragaman yang tinggi disebabkan jumlah jenis tumbuhan paku yang ditemukan pada daerah tersebut lebih banyak dibandingkan pada daerah lembah dan bukit. Daerah dengan topografi yang relatif datar memiliki variasi pohon tegakan. Hal ini mempengaru hi variasi faktor lingkungan di sekitar atas lantai hutan sehingga menjadi lingkungan yang sangat baik bagi variasi tumbuhan paku (Surfiana et al., 2018). Sedangkan rendahnya keanekaragaman tumbuhan paku 
pada daerah bukit dapat dipengaruhi oleh faktor lingkungan yang kurang mendukung pada sebagian spesies, meliputi faktor tingginya suhu udara akibat tingginya keterpaparan cahaya matahari hingga ke lantai hutan, akibatnya tingginya intensitas cahaya dan rendahnya kelembaban udara serta tingginya kecepatan angina (Imaniar \& Murdiyah, 2017).

Indeks keanekaragam seluruh jenis tumbuhan paku yang berada pada luas area $240 \mathrm{~m}^{2}$ di Kawasan Hutan Suaka Margasatwa Lambusango Desa Kakenauwe Kecamatan Lasalimu Kabupaten Buton, secara keseluruhan menunjukkan bah wa nilai indeks keanekaragamannya adalah sedang. Indeks keanekaragaman sedang menunjukkan jumlah jenis di antara jumlah total individu seluruh jenis yan g ada adalah sedang, artinya rasio jumlah individu suatu jenis dengan jumlah total individu seluruh jenis adalah sedang (Ceri et al., 2014). Jika nilai H' lebih kecil dari 1 berarti keanekaragaman jenis rendah, jika $1-3$ berarti keanekaragaman jenis sedang, dan jika lebih besar dari 3 berarti keanekaragaman jenis tinggi (Ruma \& Dominggus, 2010). Selanjutnya, semakin banyak jumlah spesies maka semakin tinggi keanekaragamannya (Putrawan, 2014). Sebaliknya, jika nilainya kecil maka komunitas tersebut didominasi oleh sedikit jenis tumbuh an (Astuti et al., 2017).

Keanekaragaman spesies tumbuhan paku ini mencerminkan stabilitas komunitas paku yang sedang pada hutan tersebut. Keanekaragaman spesies yang tinggi menunjukkan bahwa suatu komunitas memiliki kompleksitas tinggi karena interaksi spesies yang terjadi dalam komunitas itu sangat tinggi (Irma \& Herlina, 2013). Selanjutnya, melalui upaya pengamatan keanekaragaman dalam komunitas dapat diperoleh gambaran tentang kedewasaan organisasi komunitas tersebut. Biasanya makin beranekaragam suatu komunitas, makin tinggi organisasi di dalam komunitas tersebut (Surfiana etal., 2018).

\section{Kesimpulan}

Simpulan dari penelitian ini adalah jenis-jenis tumbuhan paku (Pteridophyta) di Kawasan Hutan Suaka Margasatwa Lambusango Desa Kakenauwe Kecamatan Lasalimu Kabupaten Buton ditemukan 10 suku, 14 marga dan 21 spesies. Nilai indeks keanekaragaman ( $\left.\mathrm{H}^{\prime}\right)$ tumbuhan paku pada daerah lembah, bukit, dan datar masing-masing sebesar 1,958, 1,866 dan 2,269. Penelitian ini menjadi informasi penting bahwa perbedaan topografi dapat mempengaruhi keanekaragaman jenis tumbuhan paku. Penelitian juga masih dapat dilanjutkan dengan mengkaji keanekaragaman di area sekitar air terjun dan gua dalam hutan tersebut.

\section{Daftar Pustaka}

Apriyanti, N., \& Santri, D. J. (2017). Identifikasi Tumbuhan Paku (Pteridophyta ) dan Kekerabatannya di Kawasan Wisata Air Terjun Curup Tenang Bedegung Kecamatan Tanjung Agung Kabupaten Muara Enim. Jurnal Pembelajaran Biologi, 5(November), 13-25.

Astuti, F. K., Murningsih, \& Jumari. (2017). Keanekaragaman Jenis Tumbuhan Paku (Pteridophyta) Di Jalur Pendakian Selo Kawasan Taman Nasional Gunung Merbabu Jawa Tengah. Jurnal Biologi, 6(2), 1-6. 
Ayatusa'adah, \& Nor, A. D. (2017). Inventarisasi Tumbuhan Paku (Pteridophyta) Di Kawasan Kampus IAIN Palangka Raya Sebagai Alternatif Media

Pembelajaran Materi Klasifikasi Tumbuhan. EduSains: Jurnal Pendidikan Sains \& Matematika, 5(2), 50-61.

BKSDA, S. (2018). Laporan Kinerja Tahun 2018. Balai Konservasi Sumber Daya Alam Sulawesi Tenggara (Issue 7).

Ceri, B., Lovadi, I., \& Linda, R. (2014). Keanekaragaman Jenis Paku -Pakuan ( Pteridophyta) Di Mangrove Muara Sungai Peniti Kecamatan Segedong Kabupaten Pontianak. Jurnal Protobiont, 3(2), 240-246.

Fitriasih, R., Ansori, I., Studi, P., Biologi, P., \& Bengkulu, U. (2019). Pengembangan Booklet Keanekaragaman Pteridophyta Di Kawasan Suban Air Panas Untuk Siswa SMA. Diklabio: Jurnal Pendidikan Dan Pembelajaran Biologi, 3(1), 100-108.

Imaniar, R., \& Murdiyah, S. (2017). Identifikasi Keanekaragaman Tumbuhan Paku Di Kawasan Air Terjun Kapas Biru Kecamatan Pronojiwo Kabupaten Lumajang SertaPemanfaatannya Sebagai Booklet. Jurnal Pendidikan Biologi, 6(3), 337-345.

Indriyanto. (2006). Ekologi Hutan. PT. Bumi Aksara.

Indriyanto. (2010). Pengantar Budidaya Hutan. PT. Bumi Aksara.

Irma, W., \& Herlina, N. (2013). KEANEKARAGAMAN HAYATI TUMBUHAN PAKU (Pteridophyta) DI DESA GADING SARI KEC.TAPUNG KAB. KAMPAR PROVINSI RIAU. Jurnal Photon, 4(1), 65-70.

Kinho, J. (2011). Keanekaragaman Jenis Tumbuhan Paku di Taman Nasional Aketajawe-Lolabata. Balai Penelitian Kehutanan Manado, 2 (1)(February 2014), 17-39.

Kurniawati, E., \& Rachmadiarti, F. (2010). Keanekaragaman Pteridophyta di Kawasan Hutan Wisata Air Terjun Girimanik Kabupaten Wonogiri Pteridophyta Diversity in the Area of the Forest Tourism of Waterfall Girimanik Kabupaten Wonogiri. LanteraBio, 5(1), 74-78.

Loveless, A. R. (1989). Prinsip-Prinsip Biologi Tumbuhan Untuk Daerah Tropik 2. PT. Gramedia.

Musriadi, Jailani, \& Armi. (2017). Identifikasi Tumbuhan Paku (Pteridophyta) Sebagai Bahan Ajar Botani Tumbuhan Rendah Di Kawasan Tahura Pocut Meurah Intan Kabupaten Aceh Besar. Jurnal Pendidikan Sains Universitas Muhammadiyah Semarang, 05(01), 22-31.

Muswita, Pinta, M., Indama, \& Sanjaya, M. E. (2013). Studi Keanekaragaman Jenis Tumbuhan Paku Di Taman Nasional Bukit Duabelas Provinsi Jambi. Jurnal Prosiding Semirata FMIPA Universitas Lampung, 1(1), 145-150.

Odum, E. P. (1996). Dasar-Dasar Ekologi (Ketiga). Gadjah Mada University Press.

Piggott, A. G. (1988). Frens of Malaysia In Colour. Tropical Press.

Purwanto, E. (2007). Nasionalisme Lingkungan Pesan Konservasi dari Lambusango. Deput Wahana Sinergi. 
Putrawan, I. M. (2014). Konsep-Konsep Dasar Ekologi Dalam Berbagai Aktivitas Lingkungan. Alfabeta.

Ruma, M. T. L., \& Dominggus, N. (2010). Keanekaragaman Jenis Tumbuhan Paku (Pteridophyta) Di Oehala Desa Oelekam Timur Tengah Selatan. Jurnal MIPA FST UNDANA, 8(April), 49-60.

Salamah, Z., Hadi, S., \& Aulida, Z. H. (2020). Inventory of Fern (Pteridophyta) at Cerme Cave Bantul District. Bioscience. Bioscience, 4(1), 97-108. https://doi.org/10.24036/0202041106829-0-00

Sari, H., \& Bayu, H. M. (2019). Keanekaragaman Tumbuhan Paku (Pteridophyta) di Kawasan Hutan Desa Banua Rantau Kecamatan Batang Alai Selatan Kabupaten Hulu Sungai Tengah. Jurnal Pendidikan Hayati, 5(3), 107-114.

Sastrapradja. (1980). Jenis-Jenis Paku-Pakuan Indonesia. Lembaga Biologi Indonesia-LIPI.

Steenis, C. G. G. J. Van. (2008). Flora. Pradnya Paramita.

Surfiana, Samsul, K., \& Muslich, H. (2018). Keanekaragaman Tumbuhan Paku (Pteridophyta) Berdasarkan Ketinggian Di Kawasan Ekosistem Danau Aneuk Laot Kota Sabang. Prosiding SeminarNasional Biotik, 1(1), 452-459.

Syafei, E. S. (1994). Pengantar Ekologi Tumbuhan. ITB Press.

Syafrudin, Y., Tri, S. H., \& Sri, W. (2016). Keanekargaman dan Potensi Paku (Pteridophyta) Di Taman Nasional Gunung Gede Pangrango Cianjur (TNGGP). Ekologia, 16(2), 24-31.

Uji, T., \& Windadri, F. I. (2007). Keanekaragaman Jenis Tumbuhan Di Cagar Alam Kakenauwe dan Suaka Margasatwa Lambusango Pulau Buton Sulawesi Tenggara. Teknologi Lingkngan, 8(3), 261-276.

Wanira, A., Prayogo, H., \& Tavita, G. E. (2018). Keanekaragaman Jenis Paku Pakuan (Pteridopyta) Terestrial Di Lingkungan Arboretum Sylva Universitas Tanjungpura Pontianak. Jurnal Hutan Lestari, 6(3), 548-556. 